\title{
Ameliorating the Rising Insecurity Situation in Nigeria: Skills Development Initiative through Social Sciences Education as a Lasting Tool
}

\author{
Chuks Justus Iwegbu \\ http://dx.doi./org/10.4314/ujah.v21i4.3
}

\begin{abstract}
The paper, "Ameliorating the Rising Insecurity situation in Nigeria: Skills Development Initiative through Social Science Education as a lasting Tool" has as its main thrust, the principle of using skills development initiative as a reliable too of engaging able bodied, healthy and willing men and women in order to get them out of the street in line with the popular aphorism "that an idle mind is the devils workshop "which indeed explains it all. To further appreciate this intellectual discuss, basic concepts relevant to the article such as Insecurity which is generally seen as the state of being open to danger or the uncertainty or anxiety about oneself safety is also examined. Importantly too, Skill Development Initiative is also in this discuss defined as the act of providing vocational training to people both young and old, students and even school dropouts, existing workers, and everyone interested in earning a living through practical skill etc. The concept of Social Science Education and other concepts in this discourse such as Skills, Development, Initiative and the phrase Skills Development Initiative were adequately defined etc. the paper concludes by asserting firmly that creating awareness, education and information through tactical deployment of Social Sciences Education classroom instructional process on the use of Skills Development Initiatives remains a functional and effective way of curbing the problem of dwindling insecurity problem in the Society today. Steps on how this can be effectively done through teaching and training were proffered.
\end{abstract}


Keywords: Social Science Education, Skills, Development, Initiative, Skills Development Initiative

\section{Introduction}

Skills Training and Development, though a unique aphorism among the people in both developed, developing and even among the people of the grossly underdeveloped world but it remains the most "working slang" among the people of diverse settlements in today's world. Skill Training and Development in most cases referred to as Entrepreneurship Education is today in both the classroom and in the public domain suffering with so much limitations and misconceptions. One of these popular misconceptions is that the issues of Entrepreneurship and Skill Training should only be for the unemployed and the poor, an assertion that is most ridiculous. To this end, experts on Entrepreneurship and Skills development issues could say "what a riddle, as it sounds". This negative notion is the first jinx that should be broken by this academic discourse. An additional source of income should be the meaning of Entrepreneurship and Skills devolvement effort to a gainfully employed individual irrespective of his/her monthly take home. Though the undiluted truth about the concept of Entrepreneurship and Skills development initiatives is for the unemployed who is anxious of earning a living and carving a niche for themselves. To perpetually address the ugly notion as seen above, Broad-Spectrum Entrepreneurship should be advocated. It is no longer a gainsaying to state that there is a significant relationship between unemployment and crime in societies. It therefore means that as the people are gainfully engaged, crime is expected to be dropping by the day.

\section{Concepts Clarification}

Broad-Spectrum Entrepreneurship: Broad Spectrum Entrepreneurship according to Gerald (2004), is an entrepreneurship programme that 
covers wide range of trainings. For instance, it is an entrepreneurship programme that covers such areas as commerce, industries, business, agriculture, agro allied businesses and wide range vocations that is capable of effectively engaging the unemployed and the artisans. The streamlining of Entrepreneurship and Skills development issues is one of the major reasons why the expected breakthrough from entrepreneurship is still limited. Stating further, Gerald (2004) affirmed that the impact of entrepreneurship will be massive if the content of Broad Spectrum Entrepreneurship is embraced.

Skills Development Initiative: Skills Development Initiative is an initiative or idea of teaching or training, whether formally, informally or semi-formally aimed at imparting on individuals, skills, abilities, competence and practical knowledge needed to be productive and earning a living legally. This initiative is basically important because of the unemployment situation among the developing and the underdeveloped societies in the world today. Skills are very important in the life of every human being.

Social Sciences: Social science is an academic discipline basically concerned with the study of society and the manner in which people behave and influence the world around them, (Chiemeke, 2018). Chiemeke (2018) stated further that Social Science is any discipline that deals with human behaviour in its social and cultural aspects. The social sciences include cultural (or social) anthropology, sociology, social psychology, political science, and economics. Social science tells us about the world beyond our immediate experience, and can help explain how our own society works - from the causes of unemployment or what helps economic growth, to how and why people vote, or what makes people happy. Summarily, Social sciences are a group of academic disciplines that examine society and how people interact and develop as a culture (Jike, 2002). 
Branches of Social Science: The branches of Social Sciences according to Jike (2002) include but not restricted to the following disciplines; Sociology, Economics, Political Science, Social Studies, Geography, Psychology, Social Anthropology

Security and Insecurity: Security as concept is defined by Hornby (2010) as the activities involved in securing a Country, State, Local Government Areas, Communities, Properties and Individuals. Security is freedom from, or resilience against, potential harm (or other unwanted coercive change) caused by others. Beneficiaries (technically referents) of security may be of persons and social groups, objects and institutions, ecosystems or any other entity or phenomenon vulnerable to unwanted change by its environment. Generally speaking, Security mostly refers to protection. The concept of insecurity to say the least should be considered as one of the most popular concepts in the Nigerian polity today, considering the rate of Armed Robbery, Kidnapping, Boko Haram excesses, cross border crimes and other cases of violent crimes that has become the other of the day in the Country Nigeria. It is indeed obvious that insecurity according to Harris (2014) is the general absence of Country, State, Local Government Areas, Communities, Properties and Individuals.

The whole essence of this discourse is centred on using skills development initiative through social science education as a lasting tool to the challenge of insecurity that is pervading the Nigerian Nation almost irredeemably today. Considering the economic, social, emotional and psychological effect of this hydra headed cankerworm on lives and properties. The overall need to look analytically into the obvious need on how to effectively ameliorate the psychological and emotional panic/trauma that are often associated with general insecurity on the life and properties of the people. These psychological and emotional problems associated with insecurity according to Erumesele (2016) may include but not limited to 
narcissism, schizophrenia and paranoid personalities according to Erumesele (2016). Deep-seated feelings of anxiety and insecurity often characterize these conditions, although the individuals who have these conditions may not appear to be insecure. People with a narcissistic personality Erumesele (2016) asserted, for example, may boast about accomplishments and abilities, exhibit extreme arrogance, and clearly appear to believe in their own superiority. However, these traits often conceal deeply hidden feelings of insecurity and selfdoubt, (Erumesele, 2016).

\section{Skills Development Initiative through Social Sciences Education and Their Efficacy for the Control of Rising Insecurity Situation in Nigeria}

Skills Development Initiative have earlier been defined as the idea of teaching or training people whether vulnerable or resilient to be able to maintain a certain level of self-reliance and independence not just in principle but in practice thereby making them masters of themselves. When this is done and a little comfort is achieved, little will one be expected to loiter the streets and constitute annoying nuisance to humanity in particular and the Society in general. This is indeed one major way of fighting insecurity in the land which is indeed a major menace and setback to sustainable development in any society. The major gain of Skills Development Initiative is impacting on individuals, skills, abilities, competence and practical knowledge needed to be productive and earning a living legally. This initiative is basically important because of the unemployment situation among the developing and the underdeveloped societies in the world today. Skills are very important in the life of every human being. One major fact here is that when skills are learnt and abilities and competence achieved, the is unwavering confidence that the major basic needs of man such as food, clothing and housing will be achieved and this will 
obviously reduce the pressure for crime and illegality, though degree of exception can never be ruled out.

\section{Significance of Skill Acquisition in the Society}

It is obvious that "Skilled person can survive in any environment." As water is very essential to human life, so is skill training and acquisition needed in the life of every serious minded human being. Skills can do a lot of great work in the life of every living soul. Lack of entrepreneurial skills is one of the major causes of crime, hunger, starvation, poverty, corruption in our societies today. For these reasons, Development Education Centre (DEC Enugu) during the past 3 decades engaged in the provision of entrepreneurial Skills acquisition programme which empowered over 3000 out of school female youths from 500 communities in the South East of Nigeria since its inception, Nwankwor (2018).

In 2015, Development Education Centre, Enugu (DEC) graduated over 40 well trained out of school female youths in the areas listed below as cited by Nwankwor (2018)

i. Computer Literacy

ii. Fashion \& Designing

iii. Cosmetology

iv. Catering and Hotel Management

v. Bag/Shoe making

vi. Hair Dressing

vii. Bead making.

At the Development Education Centre (DEC), Equipment's and free interest loans are always made available to the graduates of the Center according to (Nwankwor, 2018). This obviously is to enable them take off smoothly. DEC, Enugu has in the same vain introduced Business Education for these youths, to empower them with the needed knowledge and understanding on how to do business in a tough economy like Nigeria. 
The importance of Entrepreneurial skill development in our society today cannot be over emphasized because gone are the days when jobs were available everywhere both in the private and public sectors of the economy and employers go about looking for potential graduates for employment. The question of choice of job or the type of employer that one would like is now a story after graduation is now things of the old. White collar jobs are scarcely available. Hence many graduates are desperate to get any job to keep body and soul together. Indeed there is paradigm shift in the labour market. And off course, this is how the overwhelming crime rate started as people believe they must survive either by hook or by crook.

Therefore, the need to acquire and develop specific entrepreneurial skills cannot be neglected because entrepreneurship is vital to creating employment and indeed a special form of employability for graduates. Empowerment helps individuals or groups to fully access personal/collective power through knowledge, skills and motivation for proper functioning in their society and contribution to the economy (Nwankwor, 2018).

\section{The Importance of Acquiring Entrepreneurial Skills}

To state the obvious according to Chiemeke (2018), reduction in crime and criminal gang activities are the first noticeable impacts of effective and efficient empowerment and skill acquisition programmes and the other benefits of acquiring entrepreneurial skills includes but not restricted to the following

i. Self-employment: a skill acquired man is a self-employed man. A self-employed person can never go hungry because the skill he acquired provides food for him/her on a daily basis. But one who lacks skill acquisition will find it difficult to be self-employed because he/she has nothing to offer.

ii. Helps the society not to depend on white collar jobs.

iii. Helps youth develop a positive attitude towards work and labour. 
iv. It reduces poverty.

v. Helps youth to be self-reliant and independent.

Many governments are still finding it difficult to provide jobs for the citizens because the citizens are lacking important skills they need. There will be a lot of jobs generated for the citizens of every country if the citizens are well equipped with skills. This is why government should make skill acquisition programmes a priority. Arresting and executing criminals is one way out, but off course, can never be a sustained and impactful measure in the $21^{\text {st }}$ Century Crime control mechanism tolerated by most international organizations that has high regard for human rights particularly, rights to life and that of fare hearing as enshrined into United Nations Chatter on Human Rights.

\section{The Universal Declaration of Human Rights}

The Universal Declaration of Human Rights (UDHR) according to Ukadike and Ughammadu (1998) is a milestone document in the history of human rights. Drafted by representatives with different legal and cultural backgrounds from all regions of the world, the Declaration was proclaimed by the United Nations General Assembly in Paris on 10 December 1948 (General Assembly resolution 217 A) as a common standard of achievements for all peoples and all nations. It sets out, for the first time, fundamental human rights to be universally protected and it has been translated into over 500 languages. In Summary, the International Bill of Rights as recognized by the United Nations from the chatter as listed by Ukadike and Ughammadu (1998) is as follows;

i. The right to equality and freedom from discrimination

ii. The right to life, liberty, and personal security

iii. Freedom from torture and degrading treatment

iv. The right to equality before the law 
v. The right to a fair trial

vi. The right to privacy

vii. Freedom of belief and religion; and

viii. Freedom of opinion.

The fact is give the people practical and functional education, whether formal, semi-formal or informal, make them have functional skills and empower them for takeoff as this will go a long way in providing jobs for many. This indeed will work in chains as train the trainer approach (TTA), or what is colloquially called the China's Approach (CA) is encouraged to be adopted as the quickest means of reaching out to many. For instance, as Chiemeke (2018) quipped, someone who is well equipped on fashion and designing skill can train his fellow citizens. When these citizens mature in such field, they start earning from the skill they acquired. This is how the newly trained in that field will train other persons and employment generation keeps on growing in such circle. Likewise those who have good skills in business they make good money in their businesses and generate employment for others by employing others to assist him in his business.

The cheering news here according to Uche (2010) is that, the organization that employ skillful workers to assist in their organizational duties lose nothing because there is already professional mastery in place so it is always a win-win situation. The employee is employed, the employer is happy with the upsurge of output and the environment is bound to experience downward cum drastic reduction in crime. This is because the employee has acquired necessary skills needed for him to perform the work as desired by the organization. The knowledge he gained from the training on that specific job makes him to do the organizations work as desired by the management of the organization, this is what Ossai and Iwegbu (2018) referred to in their work on Principles of Entrepreneurship 
Education and Skill Development in Nigeria as "the effective working principle of you win I win".

\section{Social Sciences and Skills Development Initiative}

Social Science as seen earlier remains a discipline whose main thrust is reconstruction of man and his entire environment. Social science is the study of society and the world around. The understanding and the interpretation of the influence and the relationship between man and his entire environment whether Social, Economic, Cultural, Religious etc solely rests on the Social Sciences and the experts from the various schools of thought in the field of the Social Sciences according to (Ighodaro, 2004). Social Sciences tells us about the world beyond our immediate experience, and also help explain how our own society works - from the causes of poverty, impoverishment, unemployment, food shortage, inflation and financial misappropriation and corruption. Therefore, Ameliorating the Rising Insecurity in Nigeria, Skills Development Initiative through Social Sciences as a lasting Panacea is not divorced from the area of jurisdiction of the Social Sciences.

\section{Conclusion}

From the foregoing, it is clear that Skills Development Initiative is centrally linked security. The youths are the most energetic and active members of the entire society, so their contributions and role in national development and security need not be played down upon. However, it is evident that successive governments at the federal, state and the 704 local government areas in Nigeria have not given social and economic growth and development the needed attention it deserves, hence the high level of insecurity pervading Nigeria, its structures and Institutions and people. The most sincere conclusion from this academic discourse is that for the Nigerian state to enjoy and experience genuine commitment, patriotism, peace and security, 
Skill Acquisition and Development Initiative must be given its pride of place in Nigeria's sustainable growth and development effort.

Successful Skills Development Initiative and entrepreneurship in a growing economy need total and absolute commitment, dedication, patriotism and Political will to be impactful and sustained. If the initiative will produce the long awaited result of extreme reduction in the existing level of insecurity, high powered kidnapping, terrorism, vandalism, trafficking in persons, drug addiction and abuse, extreme poverty rate, unemployment, crime and criminal activities, deprivation, malnutrition, hunger, increased level of job and wealth creation, government at all levels should be urgently encouraged not only in the area of training and funding but also to without delay consider the immediate entrenchment of Entrepreneurship and Skill Acquisition Studies in the whole school system whether Primary School, Secondary or Tertiary Education. Also as profitable approach is that government, at the various levels (Federal, State and Local) should give priority to Skills Development and Empowerment Initiatives of both Vulnerable and all the unemployed and the weak in the Society.

Chuks Justus Iwegbu

Department of Social Studies

College of Education, Agbor

Delta State, Nigeria

cj4life001@gmail.com 


\section{References}

Chiemeke, S.C (2018) Building and Surviving in Leadership Careers in Nigeria in the Face of Massive Unemployment as a Social Scientist in Ukadike J.O (Edited) Principles of Entrepreneurship Education and Skill Development in Nigeria, Agbor

Erumesele C.M (2016) General Entrepreneurship Development: Agbor: Progress Printing Associates. Pg. 15.

Gerald E.C (2004) The relation of Entrepreneurship Education to Business Education: Simulating and Gaming: Vol 25, No 3, pp. $416-419$.

Hornby A.S (2010), Oxford Advanced Learners Dictionary of current English ( $6^{\text {th }}$ Edition). Oxford; Oxford University Press

Harris, P. (2014) A Contemporary Approach to Entrepreneurship Education and Training 46:416-423.

Ighodaro, (2004) General Entrepreneurship Development, Agbor: Progress Printing Associates.

Ikemitang, S (2017) Nigeria: Political Restructuring or Economic

Restructuring, In www.punchng.com.ng retrieved 10/012018

Iwegbu C.J \& Ossai, J.N (2018) Improving the Efficiency of Paid Labourers: The Role of Entrepreneurship Education in www.assefn.com.ng,

Jike, V.T (2002) Sociology of Development: Meaning, Scope and Relevance in the New Millenium in Journal of Social Sciences and Humanities, Vol 12, No 5

Uche E.N (2010), Introduction to Vocational Agricultural Education. Makurdi; Selfers Academic Press Ltd.

Nwankwor F.O (2018) National Economic Empowerment and Development Strategy: Lagos B3 Communications Ltd. 